\title{
Pelmatozoan arms from the Middle Cambrian of Australia: bridging the gap between brachioles and brachials?
}

\author{
SÉBASTIEN CLAUSEN, PETER A. JELL, XAVIER LEGRAIN AND ANDREW B. SMITH
}

\section{LETHAIA}

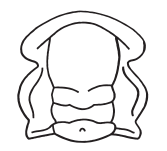

Clausen, S., Jell, P.A., Legrain, X. \& Smith A.B. 2009: Pelmatozoan arms from the Middle
Cambrian of Australia: bridging the gap between brachioles and brachials? Lethaia, Vol.
42, pp. 283-296.

The early Middle Cambrian Monastery Creek Phosphorite (Beetle Creek Formation, Queensland, Australia) contains an assemblage of disarticulated echinoderm ossicles that are exquisitely preserved. Amongst this material we recognize pelmatozoan brachials, radials, basals and holomeric columnals. Although we cannot reconstruct the complete animal with precision, these elements represent the oldest known pelmatozoan with crinoid-like appendages. Key elements include isotomously to heterotomously branched uniserial appendage plates with a tripartite adoral food groove, a longitudinal central canal interpreted as housing entoneural nerve, and differentiated articulation facets. There are also epispire-bearing radials bearing one to four arm insertion-facets, each one pierced by a central neural canal. These canals run internal towards the oral area beneath the external food groove. Co-occuring material includes single truncated cone-shaped basals and holomeric columnals, both with a similar articulation pattern, and irregular, epispire-bearing thecal plates. This mosaic of crinozoan (uniserial isotomous to heterotomous arms with neural canal), blastozoan (epispire-bearing thecal plates, appendage leading to oral thecal food groove without direct connection with body cavity) and apomorphic characters (circumoral instead of basal entoneural plexus) is unexpected and demonstrates that crinoid-like pelmatozoans with uniserial, branched arms appeared significantly earlier than the Tremadocian, when the first articulated crinoid skeletons are found. It also raises questions about the polyphyletic appearance of feeding appendages among pelmatozoan echinoderms. $\square$ Cambrian, echinoderms, functional anatomy, phylogeny, stereom.

Sébastien Clausen [sébastien.clausen@univ-lille1.fr] and Xavier Legrain [xavier.legrain@ etudiant.univ-lille1.fr], UMR 8157 - CNRS 'Geosystemes', 'Pôle Paléontologie et Paléogéographie du Paléozö̈que', UFR Sciences de la Terre, Bât. SN5, Université des Sciences et Technologies de Lille, F-59655 Villeneuve d'Ascq Cedex, France; Peter A. Jell [Peter.Jell@ brisbane.qld.gov.au], Queensland Museum, P.O. Box 3300, South Brisbane 4101, Queensland, Australia; and Andrew B. Smith [a.smith@nhm.ac.uk], Department of Palaeontology, The Natural History Museum, Cromwell Road, London SW7 5BD, UK; manuscript received on 10/3/2008, manuscript accepted on 19/8/2008.

Palaeozoic echinoderms with a stalk and an array of food-gathering appendages used for filter feeding have traditionally been classified together as Pelmatozoa (Leuckart 1848) or Crinozoa (Matsumoto 1929). Within this large group, two distinct classes, the crinoids and cystoids, have long been distinguished based on important differences in the structure of their food-gathering appendages (e.g. Burmeister 1856; Ubaghs 1968; Breimer \& Ubaghs 1974). However, more recently these two groups have been elevated to subphylum rank by Sprinkle (1973) under the names Crinozoa and Blastozoa, and their close relationship was questioned.

Crinoid appendages (referred to as arms or brachials) usually branch regularly and are supported by stout, uniserially arranged, v-shaped ossicles (Fig. 1A). Running up the v-shaped notch is a branch of the radial water vessel from which an array of tube-feet arises. Below this are extensions of the somatocoel, genital rachis and hyponeural (adoral) and entoneural (aboral) nervous systems, the last often enclosed within the skeleton, forming a clear radial perforation (Heinzeller \& Welsch 1994; Bohn \& Heinzeller 1999). These arms (brachials) connect to a well-defined facet on radial cup plates, which also has a v-shaped notch, providing direct connection to the interior of the cup. In some forms the ambulacra pass along the surface of the oral tegmen to a central mouth, but there are no flooring plates underlying the radial water vessel in this portion. Food passes to the mouth via these uncalcified channels running immediately beneath the tegmen. The entoneural nerve continues from the arm and passes into the interior of the cup plates through an opening in the facet. These nerves converge at the base of the cup, forming a radial network within the skeleton. However, many Palaeozoic crinoids lack a clear perforation running through their arm ossicles and thus may not have had such a well-developed hyponeural nerve system as is seen in extant crinoids. 

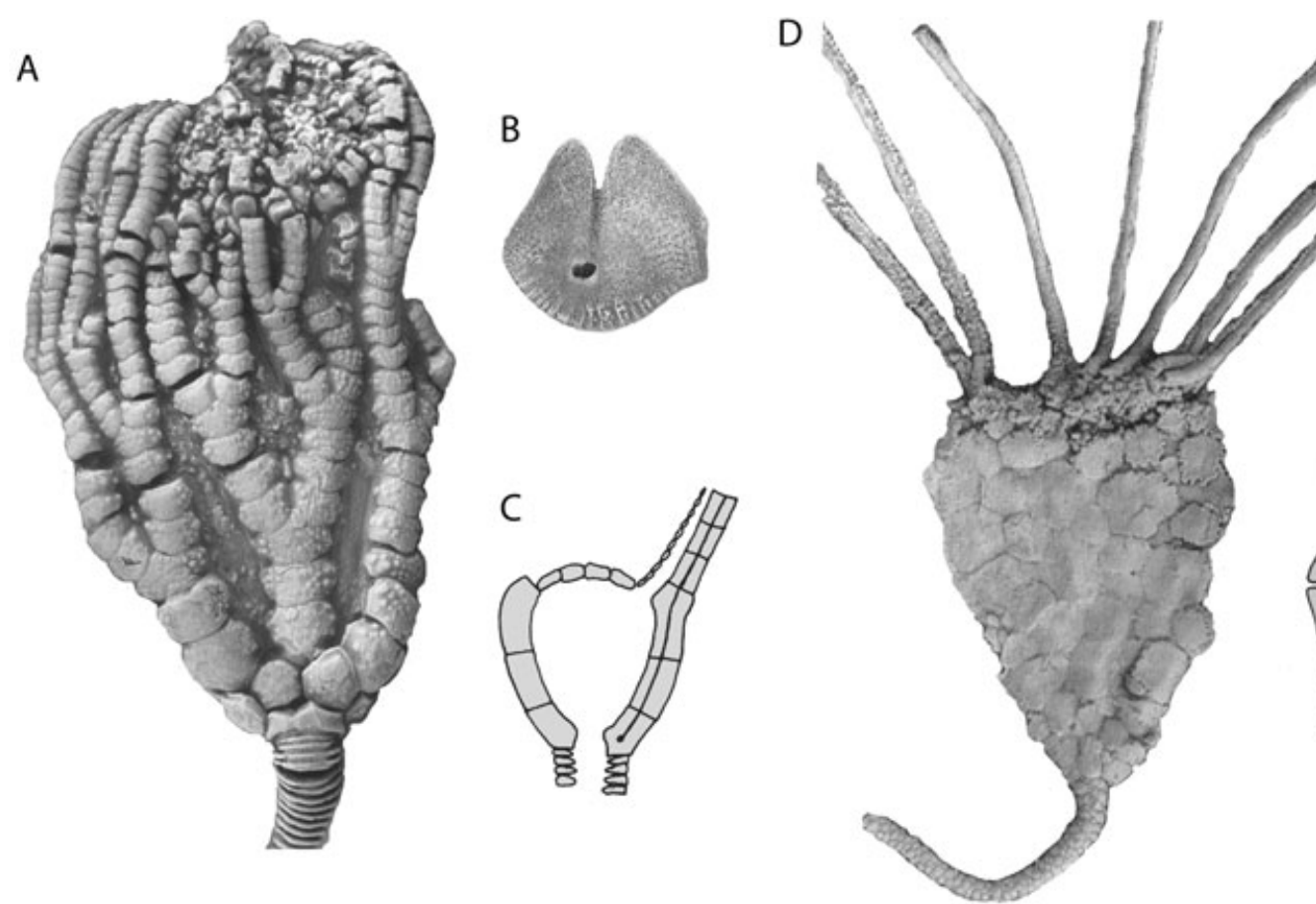

$\mathrm{E}$

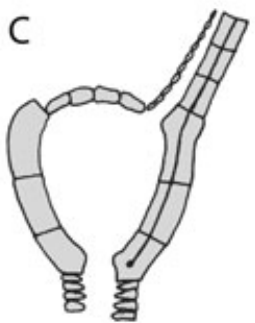

Fig. 1. Schematic cross-section through a crinozoan (Fig. 1A-C) and a blastozoan (Fig. 1D-F) showing the major differences in body organisation of theca and feeding appendages between the two groups. A. Protaxocrinus (Crinoidea, Flexibilia), showing arms, cup and top part of the stem. B. Proximal view of a uniserial arm ossicle of a crinoid; C. Schematic cross-section through a crinoid showing the direct connection between arm and body cavity. D. Gogia (Blastozoa, eocrinoid). E. Detail of an eocrinoid brachiole in adoral view (upper) and lateral view (lower) (from Ubaghs 1967). F. Schematic cross-section through an eocrinoid showing the lack of direct connection between appendages and body cavity.

Blastozoans are extinct but have been interpreted as having a very different and nonhomologous appendage structure - confusingly termed brachioles (Ubaghs 1968; Sprinkle 1973, 1976). Brachioles are free, fingerlike appendages supported by skeletal elements that, like arms, also have a v-shaped ventral groove (Fig. 1B). These appendages are typically unbranched and have biserially arranged plates. However, they are rarely perforated and so, apparently, lack an extension of the aboral nerve. Brachioles attach to facets on cup plates, sometimes entirely situated on one plate, sometimes shared between two plates. Often there is more than one attachment facet per plate, as in diploporites. These facets are horseshoe-shaped, but in marked contrast to crinoid arms, they pass into an external food groove rather than connecting directly with the interior of the cup. There is, therefore, no opening at the attachment point of the brachioles leading directly into the theca - rather they are connected to the peristome via external grooves on the surface of the theca. These external grooves converge on the mouth and are underlain throughout either by ambulacral flooring plates or cup plates.

The lack of evidence for hyponeural nerves or direct connection to the interior of the theca in
Blastozoa initially led Sprinkle (1973) to argue that the blastozoan food-gathering appendage lacked even a water vascular system and tube-feet. However, Breimer \& Macurda (1972) had earlier presented evidence that blastoids had a well-developed water vascular system in their brachioles, and subsequent authors (e.g. Breimer \& Ubaghs 1974; Paul \& Smith 1984; David et al. 2000) have all accepted that such a system was present in all blastozoan brachioles. Sprinkle (1973), Breimer \& Ubaghs (1974) and Ubaghs (1968) all agreed that no somatocoel, haemal or hyponeural nerve extensions from the body cavity extended into the brachioles of blastozoans. Indeed, Breimer \& Ubaghs (1974) went on to speculate that there was a significant difference in the nature of the innervation of brachioles and arms, with brachioles being served (presumably) by the oral (ectoneural) nervous system and arms served by the aboral or hyponeural nerve complex.

These differences also played a major part in David et al.'s (2000) phylogenetic analysis of primitive echinoderms. Arms and brachioles were seen as fundamentally different structures evolved independently and each defining a monophyletic group. In effect, David et al. argued that brachioles were composed of 
free flooring plates (axial), whereas crinoid arms were constructed from a prolongation of aboral skeleton (extraxial) with flooring plates having been lost. Support for this interpretation recently come from the reported find of a crinoid that has arms with three series of plates - paired cover plates, paired flooring plates and uniserial extraxial plates (Guensburg \& Sprinkle 2003). Full details of this animal have yet to be published.

Nevertheless, despite these obvious differences in derived members of the blastozoan and crinozoan clades, there are some groups where the distinction in the structure of the appendages is less clear-cut. Paracrinoids, for example, (Parsley 1975) have uniserial (but unbranched) arms that connect to thecal plates without direct connection to the interior. Pleurocystitids and echinosphaeritids have stout biserial appendages that attach more or less directly onto the oral area, whereas the single biserial appendage of solutes clearly opens directly into the body cavity. Amongst Cambrian forms, the structure of the plating leading from the facets over the oral tegmen to the peristome of gogiids has never been clarified, but in Ridersia and its close relatives (Velieuxicystis and Barroubiocystis) brachioles appear to arise directly from the edge of the oral tegmen (Jell et al. 1985; Ubaghs 1998).

This ambiguity has led some to question whether there really is such a clear-cut distinction between the blastozoan and crinozoan feeding appendages in the early stages of their evolution. For example, Ausich (1996, 1997, 1998a,b,c) argued that the first crinoids evolved from a blastozoan-like form with four cycles of plates. The implication of this is that the blastozoan brachiole is primitive and the crinoid arm derived. If true, we would expect to find some blastozoans with a more crinoid-like arm structure in the Cambrian.

So far discussion has focused on evidence derived from articulated fossils where details of skeletal structure are often difficult to observe. Isolated ossicles are often exquisitely well preserved in the Cambrian and can provide critical information that can help resolve the anatomy of problematic taxa (Clausen \& Smith 2005). Furthermore, body fossils are often quite rare and confined to beds where special preservation conditions have prevailed, whereas isolated echinoderm ossicles are much more commonly encountered within limestone sequences, the study of isolated echinoderm elements can reveal unexpected range extensions (Clausen \& Smith 2008). We describe here new material of a pelmatozoan with uniserial appendages from the Middle Cambrian of Australia, which seems to bridge the divide between crinozoans and blastozoans and which raise questions about whether brachioles and brachials are really independently evolved.

\section{Material and methods}

The ossicles described here were collected from Middle Cambrian rocks of the Burke River Structural Belt, in the fault-bounded sedimentary sub-basin Duchess Embayment located in the south-western part of the Georgina Basin, Australia. The Georgina Basin is a broad depression covering approximately $325000 \mathrm{~km}^{2}$ in north-western Queensland and eastcentral Northern Territories (Fig. 2A). It formed as part of the intracratonic Neoproterozoic superbasin, which was later disrupted by compressional phases into a series of related, but independent, basins occupying Central and North Australia (see e.g. Walter et al. 1995; Lindsay 2002; Lindsay et al. 2005 for reviews). Although some early Cambrian marine deposits have been described in the southern part (Walter et al. 1979), it was only in the Middle Cambrian that marine environment prevailed throughout the basins. In the Duchess Embayment area (Figs 2B, 3), the lower Middle Cambrian sedimentary succession has been divided into the Mount Birnie Beds (sandstone-conglomerate), the Thorntonia Limestone Formation (organic-rich dolomite), the Beetle Creek Formation (chert-siltstone to limestone-phosphorite) and Inca Formation (silt-chertshale). According to the sequence stratigraphic framework of Southgate \& Shergold (1991) and Gravestock \& Shergold (2001), the first two units represent lowstand to highstand system tracts of their sequence 1 (with a poorly developed transgressive system tract) deposited on a carbonate ramp under rapid subsidence. The Beetle Creek and Inca formations belong to a progradational parasequence of a transgressive system tract during a second, deepening sequence. The Beetle Creek Formation can be further subdivided into a lower organic rich phosphatic facies (siltstone member), which represents deposits within areas of restricted circulation or a relatively deep-water setting and an overlying Monastery Creek Phosphorite Member composed of intraclastic, bioclastic phosporites accumulated on a structural high and adjacent attendant slopes (Russel \& Truman 1971; Southegate \& Shergold 1991; Gravestock \& Shergold 2001).

The echinoderm material reported here comes from a phosphatic, bioclast-rich limestone within the Monastery Creek Phosphorite Member, Beetle Creek Formation. This calcareous facies has yielded a rich and diverse fauna of trilobites, molluscs (s.l. including hyolithids), bradoriids, poriferans, protohertzinia, 


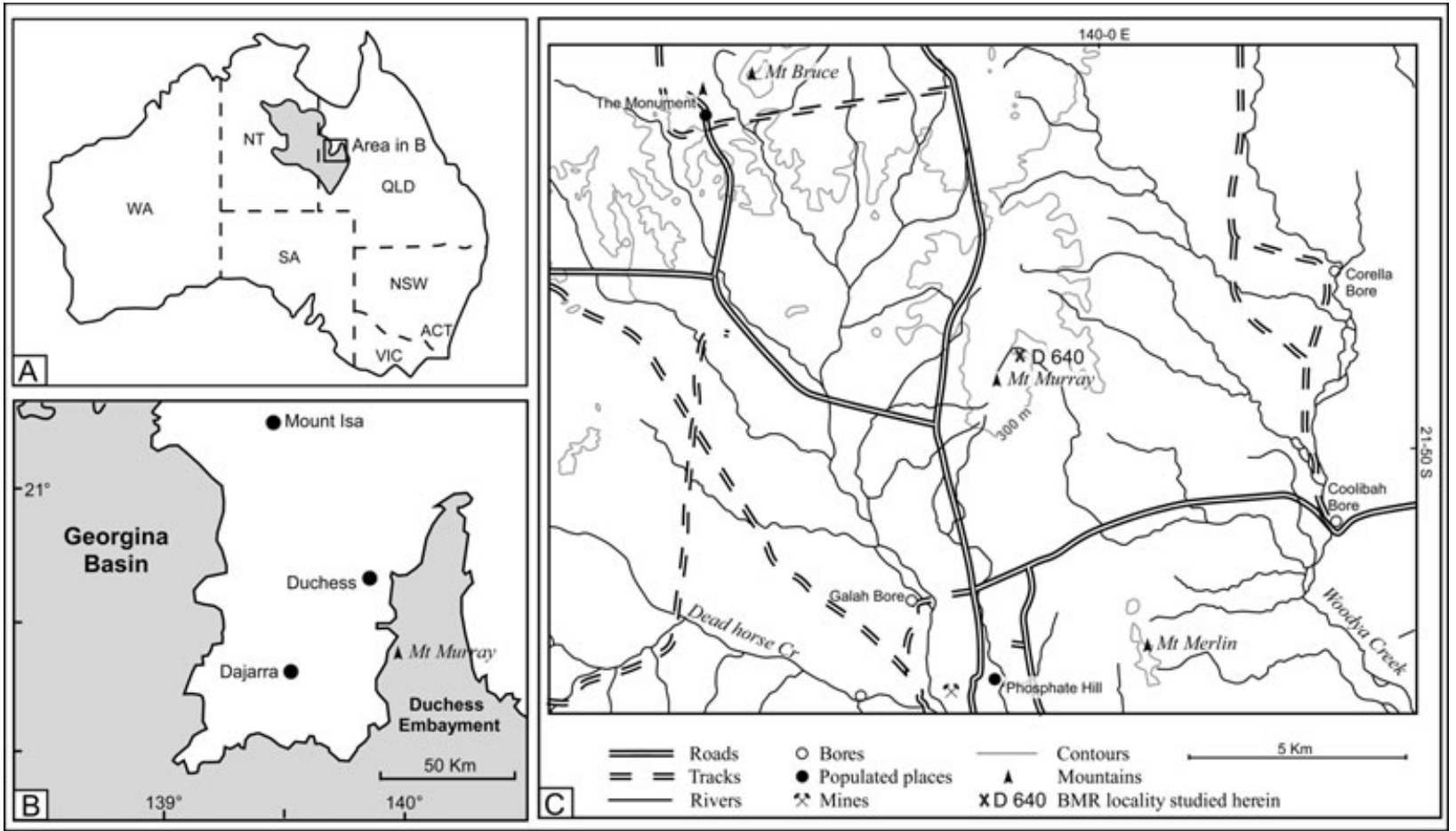

Fig. 2. Setting of the Mount Murray area in the Duchess Embayment of the Georgina Basin, in the north-western Queensland and east central Northern Territories (A-B; after Porter 2004) and geographic location of the BMR locality D640 north from Mount Murray (C; after Jones and MacKenzie, 1980; map produced using MapConnect web Mapping http://www.ga.gov.au/mapconnect using Topographic 250K Geodata 3 data).

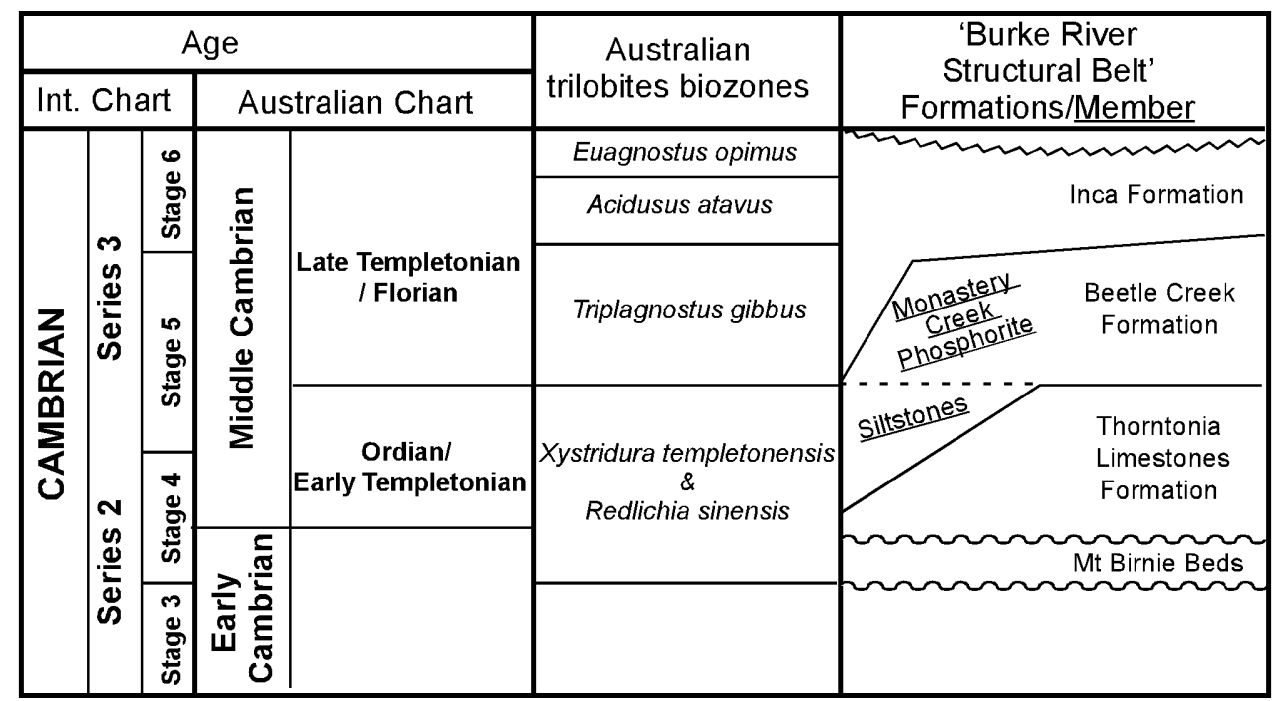

Fig. 3. Stratigraphic chart for the Cambrian second and third series transition in the Duchess Embayment area (after Southgate \& Shergold 1991 and Gravestock \& Shergold 2001).

chancelloriids, hyolithelminthids, crustacean debris, paleoscolecidae, and halkieriids (Shergold 1968, 1984; Jell 1970, 1975; Fleming 1973; Öpik 1979; Jones \& McKenzie 1980; McKenzie 1983; Shergold et al. 1985; Shergold \& Brasier 1986; Müller \& Hinz-Schallreuter
1993; Porter 2004). Although echinodermal debris has often been mentioned, this is the first study that describes any of these materials in detail. This faunal assemblage belongs to the Triplagnostus gibbus/ Acidusus atavus zones and is Late Templetonian/ 


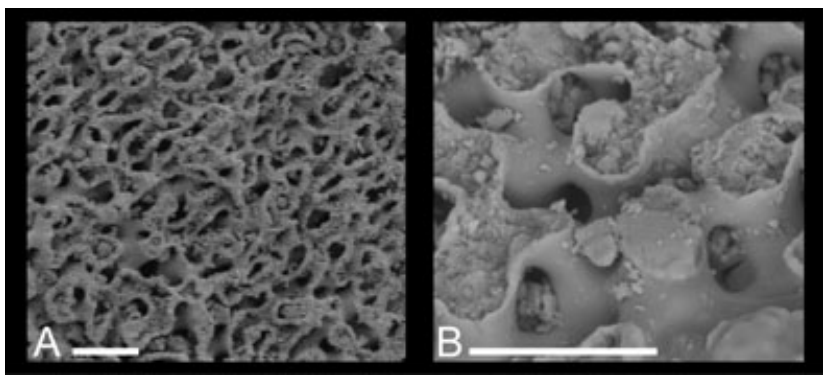

Fig. 4. Scanning electron microscopy image of echinoderm ossicles showing detail of stereom microstructure preserved as A. calcite (dissolved during etching) and B. phosphate replacement, both overlain by a coating of phosphate. Scale bars represent $25 \mu \mathrm{m}$.

Early Florian in age according to the Australian correlation chart of Gravestock \& Shergold (2001, Fig. 3). This corresponds to stage 6 of the third Cambrian Series according to provisional stratigraphic tie points given by Babcock \& Peng (2007) and to the middle 'Middle Cambrian' of traditional chart before its formal division into four series by the International Subcommission on Cambrian Stratigraphy in 2004 (Geyer \& Shergold 2000; Babcock et al. 2004; Babcock \& Peng 2007).

For this study, a bioclastic rich limestone was sampled from the Bureau of Mineral Resources (BMR) locality D640 (about $1.6 \mathrm{~km}$ to the north from Mount Murray, at approximately $139^{\circ} 59^{\prime} \mathrm{E}, 21^{\circ} 48^{\prime} \mathrm{S}$ on the Duchess 4-mile Geological Sheet; Fig. 2C), a locality previously studied for bradoriids (Jones \& McKenzie 1980), trilobites (Shergold 1968; Jell 1970, 1975) and Paleoscolcidae (Müller \& Hinz-Schallreuter 1993). The limestone was etched with $10 \%$ acetic acid. Residues were sieved using $1 \mathrm{~mm}$ and $200 \mu \mathrm{m}$ meshes before being sorted under binocular microscope and prepared for scanning electron microscopy (SEM) observation. Contrary to previous studies on Monastery Creek Phosphorite (e.g. Müller \& Hinz-Schallreuter 1993; Porter 2004), the particular lens sampled was rich in echinoderm debris, constituting up to $90 \%$ of the obtained fossil assemblage depending on fraction. Along with the pelmatozoan material described in succeeding discussions (uniserial free-appendage ossicles, appendage-bearing thecal plates, basals, columnals and holdfast), Stromatocystites ambulacral ossicles, indeterminate epispire-bearing thecal plates, and stylophoran appendage ossicles have all been identified.

Preservation of ossicles is generally excellent, including their three-dimensional stereom ultrastructure. Although some ossicles show a slight phosphatization rim to an original calcium-carbonate skeleton, most now consist only of an interconnected network of thin, hollow phosphatic tubes. This represents an early diagenetic coating that has encased the stereom trabeculae (the original calcite having been subsequently dissolved, probably during etching; Fig. 4A). Sometimes the stereom pore space has been filled by a second phosphatization phase, and this filling is generally confined to the exterior of plates (Fig. 4B).

All figured material is housed in the Natural History Museum, London (NHM).

\section{Results}

Branched and unbranched uniserial arm ossicles, thecal plates, including plates with arm facets, epispire-bearing elements, basals, columnals and small holdfasts were all present in the sample. Each will be described in succeeding discussions.

\section{Free appendage ossicles}

Both uniserial brachitaxial ossicles (unbranched elements) and uniserial axillaries (bifurcating elements that give rise to two appendage branches) can be recognized.

Arm ossicles (brachials, more than 50 specimens, Fig. 5A-C) are cylindrical elements with an oval cross-section, rounded to slightly concave latus and a concave oral furrow. They range from 400 to $600 \mu \mathrm{m}$ in length and 250 to $750 \mu \mathrm{m}$ in height, with a width to length ratio of 0.5 to 1 . At each end there are flat articulation facets that are ovate in outline. A longitudinal food groove (up to $60 \%$ of ossicle width and about $20 \%$ of ossicle in depth) runs along the entire length of the oral surface. This is a complex structure, composed of a central furrow (forming approximately $30 \%$ of the food-groove width), flanked by a pair of lateral shallow furrows. These lateral furrows are separated from the central furrow by two low and narrow ridges. There are no transverse channels linking the median furrow to the lateral furrows. Distal to these the outer wall of the food groove is oblique and slightly concave and bears two or three relatively large, shallow, spoon-shaped depressions, each prolonged by a notch on the lateral 

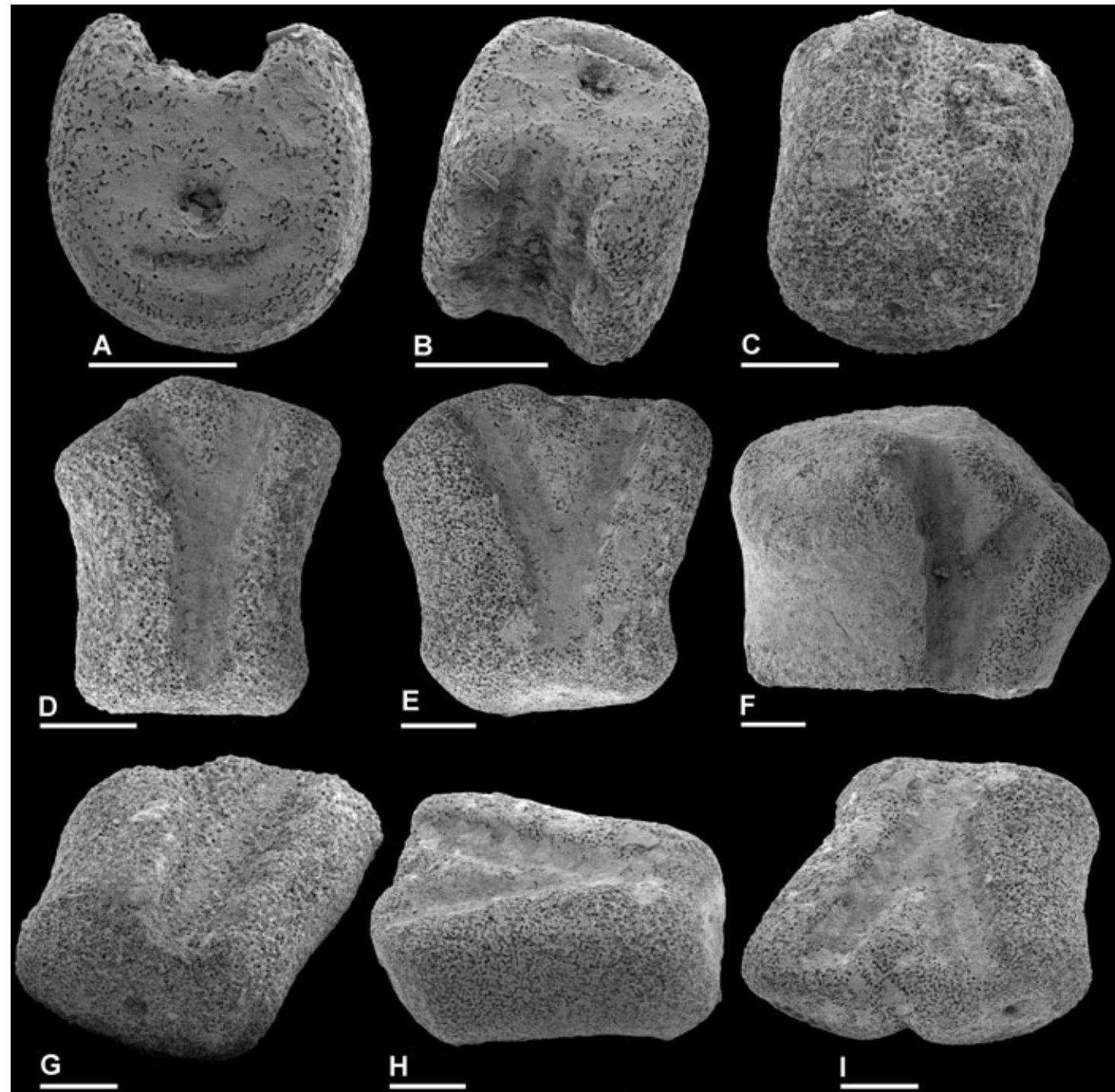

G

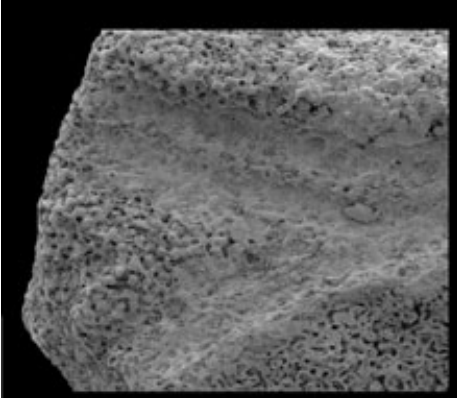

$\mathbf{J}$
H

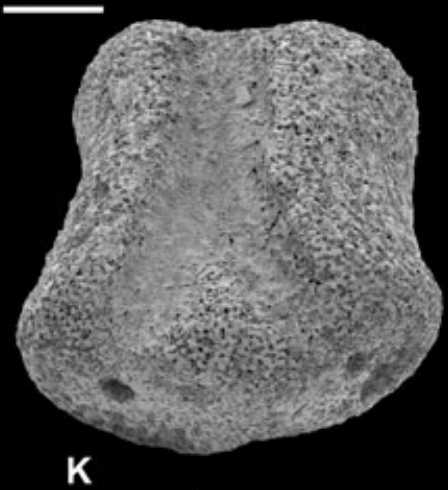

I

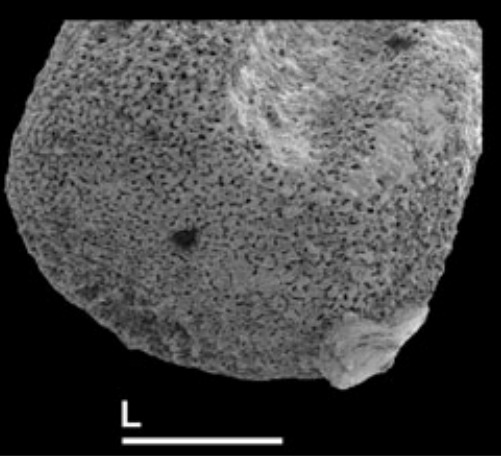

Fig. 5. Scanning electron microscopy images of uniserial brachitaxial (A-C) and axillary (D-L) ossicles. A-B. BNHM EE13349; upper view of articulation facet (A) and oblique adoral view of brachitaxial ossicle (B). C. BNHM EE13350; oblique view of brachitaxial with well-preserved coarse stereom underlining adoral furrow. D-F. BNHM EE13351-3; adoral views of axilliary ossicles with branching patterns varying from isotomous (D) to heterotomous (F). Note crenulated lateral wall of adoral furrow in F. G. BNHM EE13354; oblique lateral view of proximal facet and adoral food groove with regular, lateral spoon-shaped depressions. H-J. BNHM EE13352; oblique lateral and distal views of axillary ossicle showing bifurcating pattern of adoral food groove when distal facets are clearly distinct (detailed in J). K. BNHM EE13355; oblique view of confluent distal facets with canal lumens similar in size and aboral, crenulated cresent-shaped pits. L. BNHM EE13356; oblique view of typical (proximal) facet. Scale bars represent $200 \mu \mathrm{m}$. 
crest. These concavities are offset on each side of the ossicle and are separated from each other by convex regions, giving this inner wall a crenulated aspect in lateral view. The proximal and distal edges of the outer wall of the oral groove are always curved and, thus, do not form part of the articulation surface. Proximal and distal articulation surfaces are identical. They are hoof-shaped and bounded by a peripheral rim $(10 \%$ to $15 \%$ of articulation surface in width). This rim bears faint radial crenellae around its aboral part. There is an almost central, rounded to oval perforation ( $10 \%$ to $15 \%$ of brachial diameter) running directly beneath the food groove through the ossicle. A D-shaped or crescentic pit occupies the dorsal (aboral) part of the articulation facet, between the peripheral rim and the median perforation, whereas a pair of shallow pits lies oral of the central perforation.

Elongated pentagonal to Y-shaped axillaries (about 40 specimens, Fig. $5 \mathrm{C}-\mathrm{L}$ ), 700 to $850 \mu \mathrm{m}$ in length, 300 to $650 \mu \mathrm{m}$ in proximal width, have the same morphology as brachitaxial ossicles but branch isotomous (Fig. 5D) to slightly heterotomous (Fig. 5EF) towards their distal end. Bifurcation is either symmetric or weakly asymmetric depending upon where branching occurs along the ossicle. Axillaries with symmetric bifurcation have the two equal-sized distal facets oriented at about $33^{\circ}$ from the brachitaxial part, giving a symmetric $\mathrm{v}$ shape to each latus (Fig. 5D). Axillaries that bifurcate asymmetrically have one facet more or less aligned to the proximal brachitaxial facet, with the other oriented up to $45^{\circ}$ from it (Fig. 5F). The bifurcation is mirrored by the division of the oral furrow (Fig. 5E-F). The division of this furrow occurs between $1 / 3$ to $2 / 3$ of the length of the ossicle from the proximal facet. The distal food grooves are of similar width but are each slightly narrower than the proximal food groove prior to bifurcation. The outer walls of the oral groove bear four or five spoon-shaped depressions (Fig. 5F-G). Facets have the same morphology as those on brachitaxial ossicles (Fig. 5J-L), although shallow pits, oral to the central perforation, are never so well developed. The distal pair of facets ranges from being clearly distinct to more or less confluent (Fig. 5D, F, K). Well-separated facets are always associated with a median bare $\mathrm{v}$-shaped ridge separating the two food grooves on the oral surface and a furrow faintly prolonged on the distal face between facets (Fig. 5H-I, L). Where the two facets touch or become confluent, the facets interrupt the adoral ridge (Fig. 5F, K). Facets at the distal end are smaller than the facet at the proximal end, but the precise difference in size between facets at the two ends is variable. Distal canal lumens are similar in size on the two distal facets
(Fig. $5 \mathrm{~K}$ ), but smaller than that on the proximal facet (the ratio of distal to proximal canal-lumen ranges from about 0.3 to 0.8 ). No correlation exists between the proximal lumen diameter (60 to $70 \mu \mathrm{m}$ when observed) and the diameter of proximal facet (350 to $480 \mu \mathrm{m})$ or distal facet size $(230$ to $450 \mu \mathrm{m})$ and relative lumen diameter (20 to $65 \mu \mathrm{m})$, although in general the bigger the facets, the bigger its lumen. The diameter of the proximal facet is independent of the length of the ossicle, so that the length of axillaries most probably varies irregularly along the appendage.

The stereom forming the floor of the furrows is usually filled secondarily and obliterated; but when well preserved it is constructed of a coarse open meshwork (Fig. 5C-L). A similar coarse open meshwork floors the food groove in at least some modern crinoids (e.g. Macurda \& Meyer 1975, pl. 24, figs 5, 6).

Interpretation. - By comparison with crinoid brachials and axillaries, the aboral and paired oral pits on the articulation facet described above most probably housed connective tissue. This is supported by our observation of galleried stereom in these regions. There is, however, no clue of differentiated laterooral zones of fine stereom and we deduce that welldeveloped oral muscle fields were absent. The central canal we presume housed a major branch of the suboral (entoneural) nerve, as does the identical structure in living crinoids. Exactly what tissues lined the oral food groove is impossible to deduce. In crinoids the oral groove houses extensions of the radial water vessel and associated tube feet, ectoneural and hyponeural systems, a haemal system and both left and right somatocoels. Our observation that the food groove is complex with a tripartite structure suggests that more than just the water vessel ran along this groove. Camerate crinoids have the same tripartite organisation of their food groove, and the lateral furrows have been tentatively interpreted as housing the two longitudinal hyponeural strings (Haugh 1973). The spoon-shaped depressions along the lateral walls of the food groove match identical structures seen in the pinnules of crinoids where they mark the seating of cover plates.

\section{Thecal plates}

The thecal plates described include facet-bearing plates (probably radials sensu Ausich 1998c) and basals.

\section{Facet-bearing plates}

These five specimens (Fig. 6) are complex-shaped plates, approximately subcircular to oval in outline and 

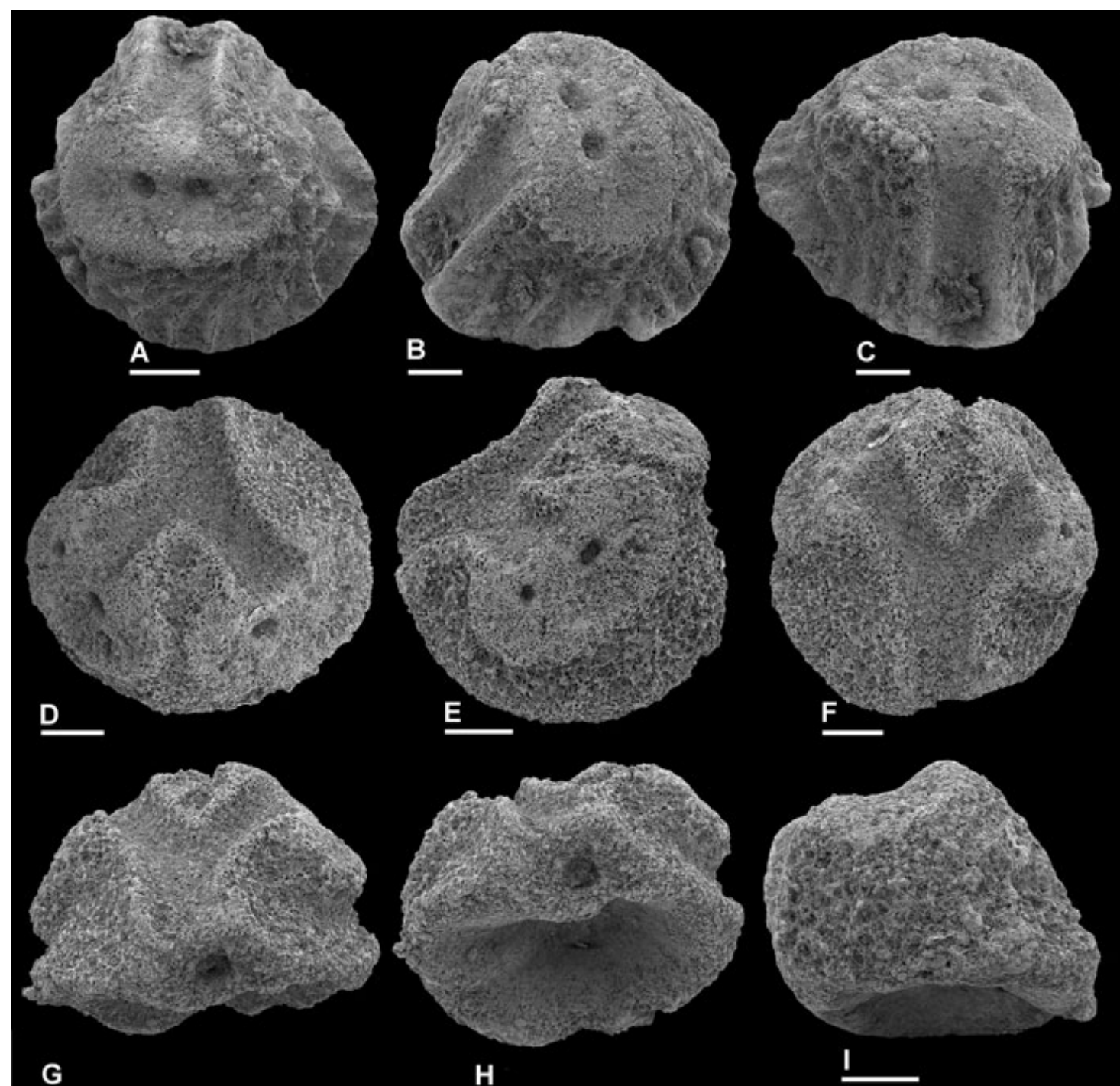

G

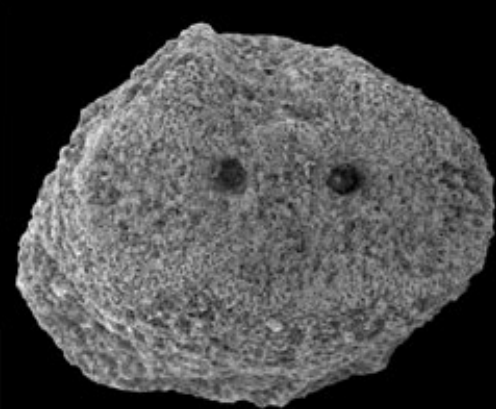

$\mathbf{J}$
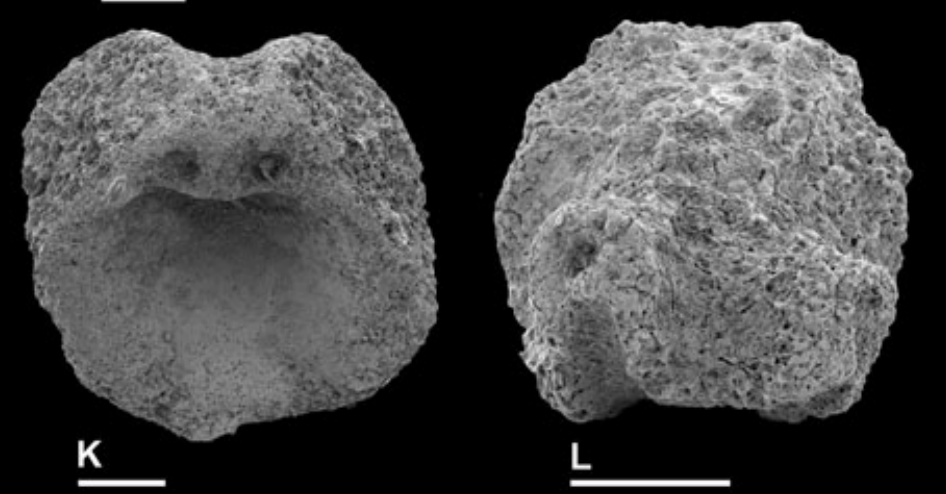

Fig. 6. Scanning electron microscopy images of facet-bearing thecal plates (radials). A-C. BNHM EE13357; upper, lateral and adoral views of radial plate bearing one prominent prong with two confluent facets, and distinct epispires. D-H. BNHM EE13358. D-F. Upper, lateral and adoral views of radial bearing two prominent prongs with two confluent facets each. G-H. Adoral and oblique view of adoral abutment facet (perforated by a canal) and concave inner surface. I-K. BNHM EE13359; lateral, distal and inner views of plate bearing two partly fused, distal insertion-facet and having two adjacent canal-openings on adoral abutment facet. L. BNHM EE13360; upper (distal) view of plate bearing two elongated prongs with one attachment facet on each. Scale bars represent $200 \mu \mathrm{m}$. 
strongly concavo-convex in cross-section. On the external face there are one to two slightly truncated conical to cylindrical prong(s) bearing appendage facets. The two prongs may be distinct and strongly projecting (Fig. 6D-H, L), or more or less fused to form a single truncated-conical to cylindrical platform (Fig. 6A-C, I-K). Each plate bears either two or four notched facets. The precise number of facets supported by an individual plate is variable. There may be (1) two prongs bearing one brachial-articulation facet each (Fig. 6L), (2) two prongs, each bearing two confluent insertion facets that fuse into a bean-shaped surface (Fig. 6D-H), or (3) one prong bearing two confluent insertion facets that fuse into a bean-shaped to peanut-shell-shaped surface (Fig. 6A-C, I-K). Each facet, partly fused or distinct, resembles in general characters the facets of brachitaxial and axilliary articulation facets. Like the arm plates, each thecal plate facet is pierced by a canal, but this is positioned closer to the oral notch than it is on brachitaxial and axilliary arm plates (where the canal is central), and the aboral crescent-shaped pit is offset laterally compared to its position on brachitaxials and axillary plates (Fig. 6BC). The diameter of the canal ranges from 40 to $180 \mu \mathrm{m}$ (about 10\% of insertion facet width). A single food groove runs externally across the plate from one face, branching dichotomously such that a branch leads to each facet. The width of this groove is 80 to $225 \mu \mathrm{m}$ (approximately 15-25\% of the plate diameter, independently of the latter), and the facets and distal food grooves are fanned out.

The external surface of the plate is rugose and covered by coarse epistroma. In some specimens the plate becomes weakly crenulated towards the margin with a series of low and sharp twisting ridges and gutters (Fig. 6A-C), the latter of which lead to marginal notches (epispires). The inner face is deeply concave and covered in a rather coarse, open stereom (Fig. 6H-K). There are flat abutment faces around the plate margins, marking where other thecal plates abut. The adoral abutment surface of the plate (Fig. 6G-H), which is flat to slightly concave and trapezoidal in outline (500 to $550 \mu \mathrm{m}$ long, about $50-60 \%$ of plate diameter, $200-230 \mu \mathrm{m}$ high), is perforated by a canal (100-110 $\mu \mathrm{m}$ in diameter), which we assume leads to each facet canal, branching internally. The canals in the arm ossicles thus enter the theca plate and run internally passing adorally into more perioral plates.

One thecal plate, bearing two partly fused distal insertion facets each pierced by a canal, differs in having two adjacent canal openings on the aboral abutment face (Fig. 6K). Thus, two canals pass through this ossicle one feeding to each of the distal articulation facets. The trapezoidal shape of the groove and its pattern of longitudinal ridges suggest that it commences to divide quite early on the ossicles but begins as a single groove at the proximal face.

At least two other forms of thecal plate are present rarely in the sample, one with small articulation facets lacking a central canal and another with a very deep, rimmed notch to which appendage ossicles would have attached. Neither fit with the uniserial appendage ossicles described previously.

\section{Basals}

A number of plates that we refer to as basals have been found. These are single truncated conical or pyramidal plates with a basal articulation facet, an angled and facetted adoral rim, and a concave centre. The latus diverges at an angle of about $10^{\circ}$ to the main axis. These formed the base of the theca and abutted distally against the first stem ossicle. However, as we do not know the number of circlets of plates forming the theca, we cannot say anything about the homology of this plate to a basal, lintel or infrabasal plate of a crinoid cup, and we use the term basal informally. Indeed there are several eocrinoids such as Rhopalocystis that have a comparable single basal plate (Ubaghs 1963). There are several different morphologies.

The first basal morphology ((Fig. 7A-D) two specimens including one broken) has a triangular to slightly lozenge-shaped distal articulation facet and a rounded pentagonal adoral surface composed of abutment faces for overlying thecal plates. The distal facet is concave with a central, circular perforation about $100 \mu \mathrm{m}$ in width, and a marginal raised platform. The wider adoral face has a raised and facetted outer margin and a concave centre. There are five polygonal and outward-facing facets separated by weak ridges. The presence of five shallow facets suggest that, as in Rhopalocystis (Ubaghs 1963), the basal plate supported a circlet of five more proximal thecal plates. The best preserved basal is $700 \mu \mathrm{m}$ in height, $450 \mu \mathrm{m}$ and $732 \mu \mathrm{m}$ in proximal and distal width, respectively. A broken specimen shows a stereom microstructure similar to columnal microstructure type 1 of Clausen \& Smith (2008).

A second basal morphotype (four specimens, Fig. 7E-F) has a circular distal facet and a concave proximal face with three prominent projections separated by deep rounded notches. These basals range from about 750 to $1050 \mu \mathrm{m}$ high. The distal facet (about 450-670 $\mu \mathrm{m}$ in width) is concave and more or less circular in outline. The adoral face (700-1050 $\mu \mathrm{m}$ in width) has a rounded triangle outline with a central, subtriangular concavity. The projections are obliquely truncated distally, forming a flat facet, slightly 

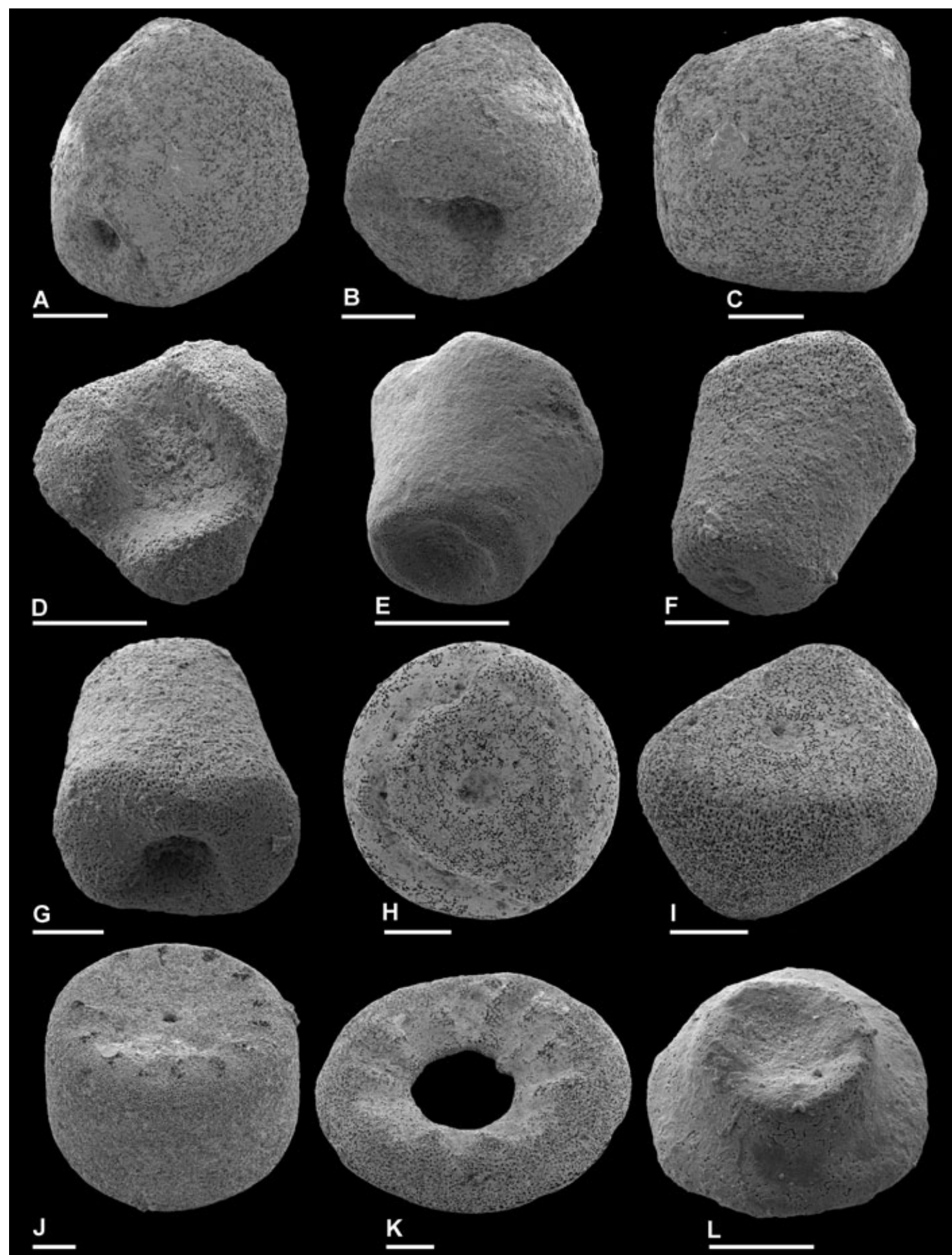

Fig. 7. Scanning electron microscopy images of basals, and tentatively associated columnals and holdfast. A-C. BNHM EE13361; distal, proximal and lateral views of basal with triangular to lozenge-shaped distal articulation and composed adoral surface. D-E. BNHM EE13362; proximal and oblique proximal view of basal with rounded distal facet and proximal facet made of three rounded projections and notches. F-G. BNHM EE13363; oblique distal and proximal views of basal with rounded distal facet and proximal articulation made of three inclined faces. H-I. BNHM EE13364-5; upper and oblique views of discoidal columnals with offset triangular facets. J-K. BNHM EE13366-7; oblique views of cylindrical and discoidal columnals with crenulated facets. L. BNHM EE13368; oblique view of truncated-cone shaped, cementedholdfast. Scale bars $=200 \mu \mathrm{m}$ except D-E $=500 \mu \mathrm{m}$. 


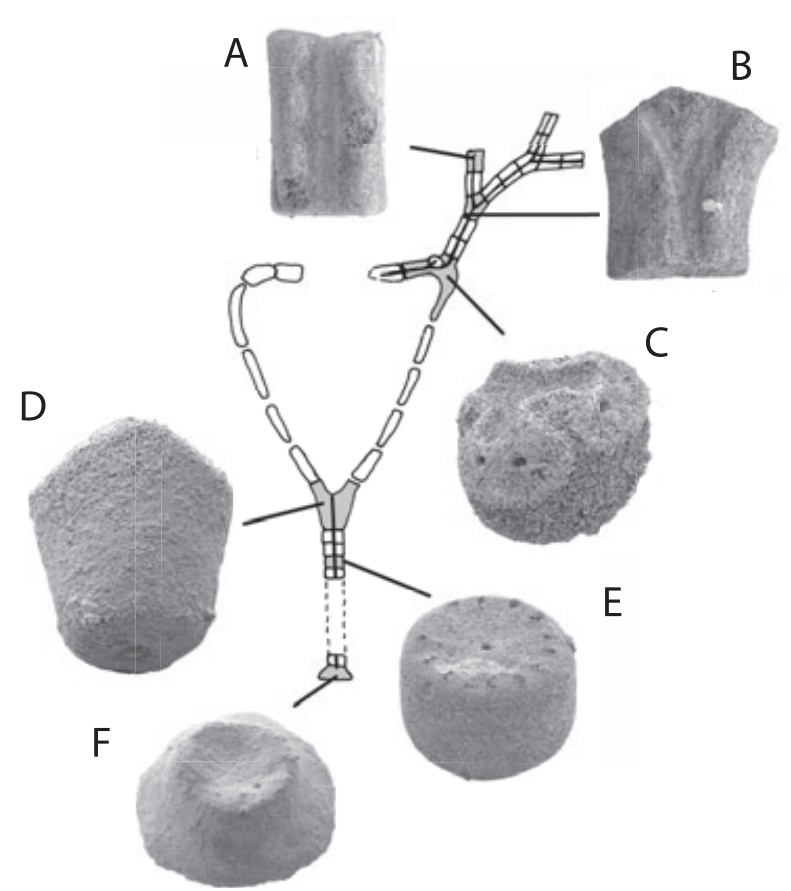

Fig. 8. Hypothetic reconstruction (cross-section) of Monastery Creek Phosphorite pelmatozoan based on disarticulated ossicles described herein. A-C. Brachitaxial, axillary and radial plates which all share an identical facet morphology. D-F. Basal, holomeric columnal and holdfast, which can only tentatively be associated with the arm ossicles.

inclined externally. Distal and proximal facets are most probably pierced by a central canal, which is infilled in all specimens.

A third type (one specimen, Fig. 7G-H) of basal has a circular and concave distal facet and an ovate proximal outline. The distal facet is similar to type 2, whereas the proximal facet is made of three externally inclined facets surrounding a central concavity. The distal and proximal facets are pierced by a $100 \mu \mathrm{m}$ and $200 \mu \mathrm{m}$ canal respectively. This basal is $680 \mu \mathrm{m}$ high, $400 \mu \mathrm{m}$ and $700 \mu \mathrm{m}$ in proximal and distal diameter, respectively.

\section{Columnals}

Columnal morphotypes (Fig. 7J-K) coming from this horizon are diverse and range from holomeric discoidal to cylindrical ossicles with a radially crenulated articulum, flanged latus and a stereom microstructure similar to type 1 columnals of Clausen \& Smith (2008), to low cylindrical ossicles (height index about $1 / 3$ ) with prominent offset triangular, slightly concave articulation facets. The latter we assume articulated with type 1 basals described previously. Rare basal attachment discs were also collected.

\section{Discussion}

We have little doubt that the facetted thecal plates and the isolated uniserial branched and unbranched ossicles come from the same animal. The facets at either end of appendage ossicles match those on the plate in both size and shape, and the width of the groove is similar in both. Furthermore, both have a similar well-developed perforation, shallow aboral ligament pit and outer radial crenellae. Our observation that some facet-bearing thecal plates have notched edges suggests that the theca included other epispire-bearing plates, and indeed all the thecal plates we found in this sample were epispire-bearing. Finally, the fact that these facet-bearing plates are rather variable in outline suggests that the theca was not composed of regular circlets of plates.

There is much less certainty about the association of basals and columnals with these thecal plates and uniserial appendage ossicles. There are clearly two different basal types and two columnal types based on the type of articulation. In one form the basal ends distally in a trigonal facet, and holomeric columnals with a similar trigonal facet are surely associated. In the other form the basal cup ends in a circular facet, whereas there are a variety of columnal shapes all with a rounded articulation facet. Which of these, is associated with the facet-bearing thecal plates, remains unknown.

The appendages were clearly branched. However, we cannot say how frequently these appendages branched. This is because branched elements are much more easily recognized than unbranched elements, and are therefore better represented in our picked sample. Nevertheless, because branched ossicles are not very much rarer than unbranched ossicles, it seems likely that the appendages branched several times.

Although we cannot reconstruct the animal in any detail we can be confident that it had: (1) multiple branching uniserial appendages; (2) a theca with a ring of appendage-bearing plates with external bifurcating food grooves; (3) most probably a single basal element; (4) other plates forming the cup, with at least some epispire bearing ones; and (5) most probably a holomeric stem. This is a very singular combination of characters seen in no other Palaeozoic echinoderm (Fig. 8). Whereas the appendages are very crinoid-like in structure the theca is typically blastozoan in its organization.

Four characters link the appendages described here with those of crinoids:

1. The arms are composed of uniserially arranged brachials. No Cambrian blastozoan is known that has uniserial appendages (we do not consider Echmatocrinus a crinoid - following Ausich \& 
Babcock 1998, 2000). Uniserial brachials are found in the crinoids (e.g. Ausich 1998c; Guensburg \& Sprinkle 2003) in paracrinoids (Parsley 1975) and in the enigmatic flattened eocrinoid Rhipidocystis (Ubaghs 1967), all of which first appear in the Ordovician.

2. The arms branch isotomously to heterotomously. Almost all blastozoans have unbranched appendages, including Rhipidocystis and the paracrinoids. In Middle Cambrian gogiids the number of appendages increases through ontogeny, but this is achieved by adding new facets to the thecal plates rather than by distal branching of the free-standing appendages (Parsley \& Zhao 2006). The only blastozoan taxa with branched (pinnulate) arms are the Upper Cambrian Trachelocrinus (Sprinkle 1973) and the rhombiferan caryocrinitids (Sprinkle 1975). In both cases the 'arms' are entirely biserial and give rise to lateral 'pinnules' whose attachment is shared between two plates. True isotomously branched arms are first seen in the earliest Ordovician crinoids (e.g. Guensburg \& Sprinkle 2003) and seem to be restricted to crinoids.

3. There is a large and well-formed canal penetrating the brachials and underlying the food groove. In crinoids this structure is well developed and houses a branch of the hyponeural nerve. A similar perforation is present in the brachials of paracrinoids (Parsley 1975) and in the eocrinoid Rhipidocystis (Sprinkle 1973). Sprinkle (1973) also reported a central perforation in the Middle Cambrian eocrinoid Gogia longidactylus, but in this form the appendage plating is biserial. The oral food groove has a tripartite structure suggestive of a complex arrangement of soft-tissue organs running along the arm, as in camerate crinoids.

4. The articulation facet has a single aboral ligament pit and paired oral ligament pits a situation seen in crinoids but as yet unreported from blastozoan brachiole ossicles.

By contrast, the thecal plates are very suggestive of a blastozoan:

1. The theca is apparently made up of an irregular mosaic of epispire bearing plates; at least the facet-bearing ossicles are not uniform in either shape or size. Moreover, all thecal plates from our sample, including the facet-bearing plates, bear epispires. Although Ausich (1988) described 11 crinoid calyx designs, all are basically constructed of a few interlocking circlets of rather uniform plates. Only a small group of articulated crinoids from the Tremadocian have irregular cup plating
(Guensburg \& Sprinkle 2003) and these do not have epispires. Epispire-bearing plates, on the other hand, are a common feature of many Cambrian and Ordovician blastozoans but have not been reported from crinozoans.

2. There is no direct connection to the interior at the point at which the appendage attaches to the cup. In the Australian beast the base of the appendage opens onto an external food groove whereas in crinoids the attachment facet is notched and leads directly into the interior of the cup. In paracrinoids there are short external grooves leading to the mouth from the base of each appendage facet.

3. The presence of a single conical basal plate to the theca is typical of rhipidocystids and Rhopalocystites, but is otherwise rarely developed except in some advanced crinoids.

In recent years it has been usual to emphasize the structural differences that exist between blastozoan and crinozoan free appendages (e.g. Sprinkle 1973; Ubaghs 1978; David et al. 2000). Whereas crinoids have arms that carry extensions of the main body coeloms (hydrocoel, somatocoel) as well as the ectoneural and hyponeural nerves, blastozoan arms have been interpreted as something much simpler, carrying little more than the radial water vessel and associated ectoneural nerve (David et al. 2000). Part of the evidence for this came from the different way in which appendages were connected to the theca, with the lumen in crinoid arms continuing directly into the cup interior, whereas blastozoan appendages led into external food grooves. Yet there is no direct evidence for what soft tissues actually sat in the blastozoan brachiole and, as noted in the introduction, there are some groups that seem to bridge the morphological gap between these two types.

Our finding of a Middle Cambrian echinoderm with crinoid-like uniserial arms and associated blastozoan-like thecal plating challenges current concepts of pelmatozoan evolution and raises questions about just how distinct the food-gathering appendages of blastozoans and crinozoans really are. At the very least we have shown that crinoid-like uniserial arms had already evolved by the middle Middle Cambrian and that these were composed of ossicles indistinguishable from those encountered in crinoids from the early Ordovician onwards. These Cambrian arm ossicles clearly carried a major branch of the nervous system, as indicated by the well-developed perforation. However, unlike modern crinoids, this nerve trunk originates from the circumoral region rather than the base of the cup. It is not clear, therefore, whether this nerve trunk represents a branch of the aboral system 
or the hyponeural system. The organization of neural system within the cup of Palaeozoic forms is still poorly known (but see Paul (1970) and Haugh (1975) for putative reconstructions) and needs to be carefully documented in light of our findings.

Because the difference in anatomical organization of crinozoan and blastozoan appendages in the Middle Cambrian may not have been so marked, it seems eminently possible that the two structures are indeed homologous, with crinoid arms derived from blastozoan precursors. The mosaic of characters displayed by our Middle Cambrian pelmatozoan suggests that crinozoan brachials first evolved in an echinoderm with a blastozoan-like thecal plate arrangement. Alternatively, it could indicate that the presence of uniserial arms is not a reliable synapomorphy for crinoids. A more complete knowledge of the thecal structure of our Middle Cambrian pelmatozoan is needed to determine whether it is an antecedent of the crinoids or has evolved uniserial arms independently.

A different interpretation for the origin of crinoid arms has been put forward by Guensburg \& Sprinkle (2003). They describe two new early Ordovician genera Titanocrinus and Glenocrinus, which they place in the new order (plesion), Protocrinoida. They report that their appendages are composed of three layers of plates (uniserial brachials with paired flooring plates and cover plates) and argue that this is the primitive condition for all crinoids. According to Guensburg \& Sprinkle (2003), the brachials of crinoids are extraxial (aboral) plates, and the crinoid arm has arisen through loss of the flooring plates. On the other hand, appendages in blastozoans comprise flooring and cover plates and lack extraxial plate elements. Unfortunately, these important specimens have not yet been described in detail. Many key characters of this arm structure and its attachment to the cup remain unknown so it is difficult for us to assess the evidence. We await with interest a more detailed description.

Finally, our unexpected discovery shows just how important the study of isolated ossicles from this critical time period can be. Most of our understanding of the early history of echinoderms comes from study of articulated or partially articulated specimens in Lagerstätte. By studying the often abundant and well preserved isolated ossicles from the Cambrian we add new information on morphology, anatomy and diversity of echinoderm types. Our work shows that uniserial arms had already evolved by the Middle Cambrian, well before the first undisputed body fossils with such structure (Tremadocian).

Acknowledgements. - SC received support from the SYNTHESYS Project http://www.synthesys.info/ which is financed by European Community Research Infrastructure Action under the FP6 'Structuring the European Research Area' Programme. This work is a contribution to ANR project (JC07_194555) 'Paleogeographic, paleoecologic, and paleoenvironmental controls on the evolution of bottom - level communities during Cambrian times' financed by CNRS-USAR. Fieldwork by ABS was funded by a Royal Society grant.

\section{References}

Ausich, W.I. \& Babcock, L.E. 2000: Echmatocrinus, a Burgess Shale animal reconsidered. Lethaia 33, 92-94.

Ausich, W.I. 1988: Evolutionary convergence and parallelism in crinoid calyx design. Journal of Paleontology 62, 906-916.

Ausich, W.I. 1996: Origin of the Crinoidea. In Mooi, R. \& Telford, M. (eds): Echinoderms: San Francisco, 127-132. A.A. Balkema, Rotterdam.

Ausich, W.I. 1997: Calyx plate homologies and early evolutionary history of the Crinoidea. In Waters, J.A. \& Maples, C.G. (eds): Geobiology of Echinoderms. The Paleontological Society Papers 3, 289-304.

Ausich, W.I. 1998a: Origin of crinoids. In Candia Carnevali, M.D. \& Bonasoro, F. (eds): Echinoderm Research 1998, 237-242. A.A. Balkema, Rotterdam.

Ausich, W.I. 1998b: Early phylogeny and subphylum division of the Crinoidea (phylum Echinodermata). Journal of Paleontology 72, 499-510.

Ausich, W.I. 1998c: Phylogeny of Arenig to Caradoc crinoids (phylum Echinodermata) and suprageneric classification of the Crinoidea. The University of Kansas Paleontological Contributions New Series 9, 1-36.

Ausich, W.I. \& Babcock, L.E. 1998: The phylogenetic position of Echmatocrinus brachiatus, a probable octacoral from the Burgess Shale. Palaeontology 41, 193-202.

Babcock, L.E. \& Peng, S. 2007: Cambrian chronostratigraphy: current state and future plans. Palaeogeography, Palaeoclimatology, Palaeoecology 254, 62-66.

Babcock, L.E. Rees, M.N., Robison, R.A., Lengenburg, E.S. \& Peng, S. 2004: Potential Global Standard Stratotype-section and Point (GSSP) for a Cambrian stage boundary defined by the first appearance of the trilobite Ptychagnostus atavus, Drum Mountains, Utah, USA. Geobios 37, 149-158.

Bohn, J.N. \& Heinzeller, T. 1999: Morphology of the bourgueticrinid and isocrinid aboral nervous system and its possible phylogenetic implications (Echinodermata, Crinoidea). Acta Zoologica 80, 241-249.

Breimer, A. \& Macurda, D.B. 1972: The phylogeny of the fissiculate blastoids. Koninklijke Nederlandse Akademie van Wetenschappen. Amsterdam, Eerste Reeks 26, 1-390.

Breimer, A. \& Ubaghs, G. 1974: A critical comment on the classification of the pelmatozoan echinoderms. Proceedings Koninklijke Nederlandse Akademie van Wetenschappen. Amsterdam B77, 398-407.

Burmeister, H. 1856: Systematische übersicht der crinoideen. Zoonomische Briefe 1 (Pt.), 241-246.

Clausen, S. \& Smith, A.B. 2005: Palaeoanatomy and biological affinities of a Cambrian problematic deuterostome (Stylophora). Nature 438, 351-354.

Clausen, S. \& Smith, A.B. 2008: Stem structure and evolution in the earliest pelmatozoan echinoderms. Journal of Paleontology 82, 737-748.

David, B., Lefebvre, B., Mooi, R. \& Parsley, R. 2000: Are homalozoans echinoderms? An answer from the extraxial-axial theory. Paleobiology 26, 529-554.

Fleming, P.J.G. 1973: Bradoriids from the Xystridura Zone of the Georgina Basin, Queensland. Geological Survey of Queensland, Publication 356, Palaeontological Papers 31, 1-9.

Geyer, G. \& Shergold, J.H. 2000: The quest for internationally recognized divisions of Cambrian time. Episodes 23, 188-195.

Gravestock, D.I. \& Shergold, J.H. 2001: Australian Early and Middle Cambrian sequence biostratigraphy with implications for species diversity and correlation. In Zhuravlev, A.Y. \& Riding, R. (eds): The Ecology of the Cambrian Radiation, 107136. Columbia University Press, New York. 
Guensburg, T.E. \& Sprinkle, J. 2003: The oldest known crinoids (Early Ordovician, Utah) and a new crinoid plate homology system. Bulletins of American Paleontology 364, 1-43.

Haugh, B.N. 1973: Water vascular system of the Crinoidea Camerata. Journal of Paleontology 47, 77-90.

Haugh, B.N. 1975: Nervous systems of Mississipian camerate crinoids. Paleobiology 1, 261-272.

Heinzeller, T. \& Welsch, U. 1994: Crinoidea. In Harrisson, F.W. \& Chia, F.-S. (eds): Microscopic Anatomy of Invertebrates, volume 14 Echinodermata, 9-148. Wiley-Liss, New-York.

Jell, P.A. 1970: Pagetia ocellata, a new Cambrian trilobite from northwestern Queensland. Memoirs of the Queensland Museum 15, 303-313.

Jell, P.A. 1975: Australian Middle Cambrian eodiscoids with a review of the Superfamily. Paleontographica A150, 1-197.

Jell, P.A., Burrett, C.F. \& Banks, M.R. 1985: Cambrian and Ordovician echinoderms from eastern Australia. Alcheringa 9, 183-208.

Jones, P.J. \& MacKenzie, K.G. 1980: Queensland Middle Cambrian Bradoriida (Crustacea): new taxa, paleobiogeography and biological affinities. Alcheringa 4, 203-255.

Leuckart, C.G.F.R. 1848: Über die morphologie und die verwantschafts verhältnisse der wirbellosen tiere. Braunschweig $8,1-$ 180.

Lindsay, J.F. 2002: Supersequences, superbasins, supercontinentsevidence from the Neoproterozoïc basins of Central Australia. Basin Research 14, 204-223.

Lindsay, J.F., Kruse, P.D., Green, O.R., Hawkins, E., Brasier, M.D., Cartlidge, J. \& Cortfield, R.M. 2005: The Neoproterozoic-Cambrian record in Australia: a stable isotope study. Precambrian Research 143, 113-133.

Macurda, D.B. \& Meyer, D.L. 1975: The microstructure of the crinoid endoskeleton. The University of Kansas Paleontological Contributions $74,1-22$.

Matsumoto, H. 1929: Outline of a classification of Echinodermata. Tokohu Imperial University, Science reports 2 (Geology) 13, 2733.

McKenzie, K.G. 1983: On the origin of Crustacea. In Lowry, J.K. (ed.): Papers from the conference on the biology and evolution of Crustacea, 1980, Australian Museum, Sydney. Memoirs of the Australian Museum 18, 21-43.

Müller, K.J. \& Hinz-Schallreuter, I. 1993: Palaeoscolecid worms from the Middle Cambrian of Australia. Palaeontology 36, 549592.

Öpik, A.A. 1979: Middle Cambrian agnostids: systematics and biostratigraphy. Bureau of the Mineral Resources of Australia, Bulletin 175, 1-85.

Parsley, R.L. 1975: North American Paracrinoidea (Ordovician: Paracrinozoa, new, Echinodermata). Bulletins of American Paleontology $68,1-115$.

Parsley, R.L. \& Zhao, Y. 2006: Long stalked eocrinoids in the basal Middle Cambrian Kaili biota, Taijiang County, Guizhou Province, China. Journal of Paleontology 80, 1058-1071.

Paul, C.R.C. 1970: The aboral nervous system of Marsupiocrinus Morris. Fieldiana Geologica 16, 461-469.

Paul, C.R.C. \& Smith, A.B. 1984: The early radiation and phylogeny of echinoderms. Biological Reviews 59, 443-481.

Porter, S.M. 2004: Halkieriids in Middle Cambrian phosphatic limestones from Australia. Journal of Paleontology 78, 574-590.
Russel, R.T. \& Truman, N.A. 1971: The geology of the Duchess phosphate deposits, Georgina Basin, Queensland, Australia. Economic Geology 66, 1186-1214.

Shergold, J.H. 1968: Cambrian Paleontology. Appendix. In De Keyser, F. (ed.): The Cambrian of the Burke River Outlier. Record of the Bureau of Mineral Ressources, Geology and Geophysics 67 (unpubl.).

Shergold, J.H. 1984: Review of Cambrian phosphatised and phosphatic faunas of the Georgina Basin, northern Australia. In Anonymous (ed.): Symposium of the 5th International Field Workshop and Seminar on Phosphorite, 209-218. Geological Publishing House, Beijing.

Shergold, J.H. \& Brasier, M.D. 1986: Proterozoic and Cambrian phosphorites-specialist studies : biochronology of Proterozoic and Cambrian phosphorites. In Cook, P.J. \& Shergold, J.H. (eds): Phosphate Deposits of the World, Volume1, Proterozoic and Cambrian, 295-326. Cambridge University Press, Cambridge.

Shergold, J.H., Jago, J.B., Cooper, R.A. \& Laurie, J.R. 1985: The Cambrian system in Australia, Antartica and New Zealand. Correlation charts and explanatory notes. Publications of International Union of Geological Sciences 19, 85.

Southgate, P.N. \& Shergold, J.H. 1991: Application of sequence stratigraphic concepts to Middle Cambrian phosphogenesis, Georgina Basin, Australia. Bureau of Mineral Ressource Journal of Australian Geology and Geophysics 12, 119-144.

Sprinkle, J. 1973: Morphology and Evolution of Blastozoan Echinoderms, Museum of Comparative. Zoology, Harvard University, Special Publication, Cambridge. 283 pp.

Sprinkle, J. 1975: The 'arms' of Caryocrinites, a rhombiferan cystoid convergent on crinoids. Journal of Paleontology 49, 1062-1073.

Sprinkle, J. 1976: Classification and phylogeny of 'pelmatozoan' echinoderms. Systematic Zoology 25, 83-91.

Ubaghs, G. 1963: Rhopalocystis destombesi n. g., n. sp. Eocrinoide de l'Ordovicien inférieur (Trémadocien supérieur) du Sud marocain. Notes du Service Géologique du Maroc 23, 25-44.

Ubaghs, G. 1967: Eocrinoidea. In Moore, R.C. (ed.): Treatise on Invertebrate Paleontology, Part S, Echinodermata 1, S455-S495. Geological Society of America and University of Kansas Press, Boulder.

Ubaghs, G. 1968: General characters of Echinodermata. In Moore R.C. (ed.): Treatise on Invertebrate Paleontology. Part S. Echinodermata 1, S3-S60. Geological Society of America and University of Kansas Press, Boulder.

Ubaghs, G. 1978: Skeletal morphology of fossil crinoids. In Moore, R.C. (ed.): Treatise on Invertebrate Paleontology. Part T. Echinodermata 2(1), T58-T216. Geological Society of America and University of Kansas Press, Boulder.

Ubaghs, G. 1998: Echinodermes nouveaux du Cambrien supérieur de la Montagne Noire (France Méridionale). Geobios 31, 809829.

Walter, M.R., Shergold, J.H., Muir, M.D. \& Kruse, P.D. 1979: Early Cambrian and latest proterozoic stratigraphy, desert syncline, southern Georgina basin. Journal of the Geological Society of Australia 26, 305-312.

Walter, M.R., Veevers, J.J., Calver, C.R. \& Grey, K. 1995: Neoproterozoic stratigraphy of the Centralian Superbasin, Australia. Precambrian Research 73, 173-195. 